\title{
Liver oxygen consumption of cold- and warm-acclimated rats and factors regulating liver oxidative metabolism
}

\author{
EUgen ZeISBerger \\ Department of Comparative Physiology, Charles University, \\ Prague, Czechoslovakia
}

KURZFASSUNG: Lebersauerstoffverbrauch kalt- und warmakklimatisierter Ratten und Faktoren, welche den oxydativen Leberstoffwechsel regulieren. Der Sauerstoffverbrauch der isolierten Leber hängt von einer Reihe von Perfusionsbedingungen (Sättigung des Bluts mit Sauerstoff, Geschwindigkeit der Blutströmung durch die Leber, Temperatur) ab. Er vermindert sich während des Versuchs auch dann, wenn die Perfusionsbedingungen konstant gehalten werden, und zwar infolge der Veränderungen des Bluts während der Rezirkulation. Daher entsprechen nur die höchsten, zu Beginn des Perfusionsversuchs gemessenen Werte des Sauerstoffverbrauchs der isolierten Leber den Werten des Leberstoffwechsels in vivo. Dies bedeutet, daß der Ruhestoffwechsel der Rattenleber viel höher ist (6 bis $8 \mathrm{ml} \mathrm{O} / \mathrm{g} \mathrm{Leber} / \mathrm{Std}$.), als man bisher auf Grund des Sauerstoffverbrauchs von Leberschnitten angenommen hat. Der durchschnittliche Ruhesauerstoff verbrauch der isolierten Leber kaltakklimatisierter $\left(6^{\circ} \mathrm{C}\right)$ Ratten unterscheidet sich signifikant von dem warmakklimatisierter $\left(30^{\circ} \mathrm{C}\right)$. Er trägt bei letzteren mit 19,3\%, bei ersteren dagegen mit 26,5\% zum Basalstoffwechsel bei; die Lebex kaltakklimatisierter Ratten produziert also unter Basalbedingungen etwa $35 \%$ mehr Wärme als die Leber warmakklimatisierter. Die Wärmebildung in der Leber kann durch Hormone, erhöhte Substratkonzentration und Veränderungen der Blutdurchströmung der Leber gesteigert werden. Die quantitative Bedeutung dieses thermogenetischen Mechanismus ist aber wahrscheinlich sehr beschränkt.

\section{INTRODUCTION}

During nonshivering thermogenesis developing in rats as a result of cold acclimation, skeletal musculature plays an important role (Depocas 1958, 1960a, b,

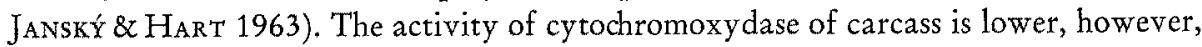
than the total increase of metabolism in cold, and the participation of other body organs in thermogenesis can therefore be expected (JANSKX́ 1963). It has been calculated that about $30 \%$ of total nonshivering thermogenesis originates in extramuscular organs (JANSKÝ 1965).

In the past, the liver was considered to be the main source of heat production in the body. This assumption was based mainly on changes in liver temperature measurements (GRAF 1959). Direct evidence for participation of liver heat production in thermogenesis was missing, however. Since it was technically very difficult to measure liver metabolism in vivo, the experiments were performed on isolated perfused livers 
of rats. The aim of these experiments was to ascertain factors which may exert an effect on the oxidative metabolism of the liver and to clarify the role of liver metabolism in basal heat production and in cold thermogenesis.

\section{MATERIAL AND METHODS}

Animals: Cold- or warm-acclimated fed male rats of the Sprague-Dawley strain were used as donors of blood and liver. They were acclimated to $6^{\circ}$ or $30^{\circ} \mathrm{C}$ for at least three weeks.

Perfusion $f 1$ u id: Twenty to $25 \mathrm{ml}$ of defibrinated rat blood were used for one experiment. In experiments in which blood was exchanged during the perfusion, a double quantity of blood was used. The donors of blood were acclimated and treated in the same way as the donors of liver.

Perfusion apparatus: A simple perfusion apparatus made from plastics was used (DoležAl, Zeisberger \& JanskÝ 1963, Zeisberger 1965). The diagram of the apparatus is shown in Figure 1. The apparatus consists of a pumping system (A) driven by an electromagnet (1), the armature of which presses a rubber tube (2), placed between two one-way valves $(3 a, 3 b)$. By compressing the rubber tube (2) the rising pulse wave expands the similar tube in relay (4), which causes disconnection of the contacts of the relay (5) controlling the electromagnet. By the release of the electromagnet the rubber tube (2), being elastic, straightens out and pumps the fluid from the reservoir (C). The pressure loosens also in the relay tube (4), which connects the contacts of the relay. This switches on the electromagnet and a new pulse begins. The electromagnet is fed by direct current of various voltage from 6 to $25 \mathrm{~V}$. Alternating current from the electrical network of $220 \mathrm{~V}$ voltage is used as a current source for the electromagnet and is transformed by a revolving regulating transformer and rectified by a simple diode rectifier. The frequency of pulses is so high that the blood flow is continual. The perfusion pressure is not constant, the maximal pressure in the system being 15 to $20 \mathrm{~mm} \mathrm{Hg}$ when the blood outflow is completely arrested. The rate of flow is roughly adjusted by a screw on the moveable contact of the relay (5). Smaller changes are achieved by voltage changes. The flow rate can be changed from $1.5 \mathrm{ml} / \mathrm{min}$ to $40 \mathrm{ml} / \mathrm{min}$.

The liver is perfused through a cannula in the vena portae (6). The cannula is attached to the metal end of the blood intake in the perfusion chamber (B). The perfusion chamber, which is made of plexiglass, is tightly closed by a glass lid so that it retains a high relative humidity, and the liver does not dry up during the experiment. The deoxygenated blood flowing out of the liver through a cannula in the vena cava inferior (7) passes through a flow meter (8) into a double oxygenator and blood reservoir $(C)$. The double oxygenator was developed in order to achieve a fast and complete exchange of perfusing blood during the experiment. The two oxygenators $(9,10)$ are completely divided and are connected with the apparatus by a double stop-cock (11) of glass covered by a layer of silicone fluid. In the oxygenator the blood is reoxygenated by flowing through a layer of fine foam of bubbles, which is formed of pre-humidified medicinal oxygen $\left(95 \% \mathrm{O}_{2}+5 \% \mathrm{CO}_{2}\right)$, supplied by a syringe 
needle (12) inserted in the blood reservoir. The column of foam is disturbed at the top of the reservoir by a silicated polyurethane sponge (13).

Oxygenation can be regulated by adjusting the height of the foam column or by using different mixtures of oxygen, nitrogen and $5 \% \mathrm{CO}_{2}$. The temperature of the

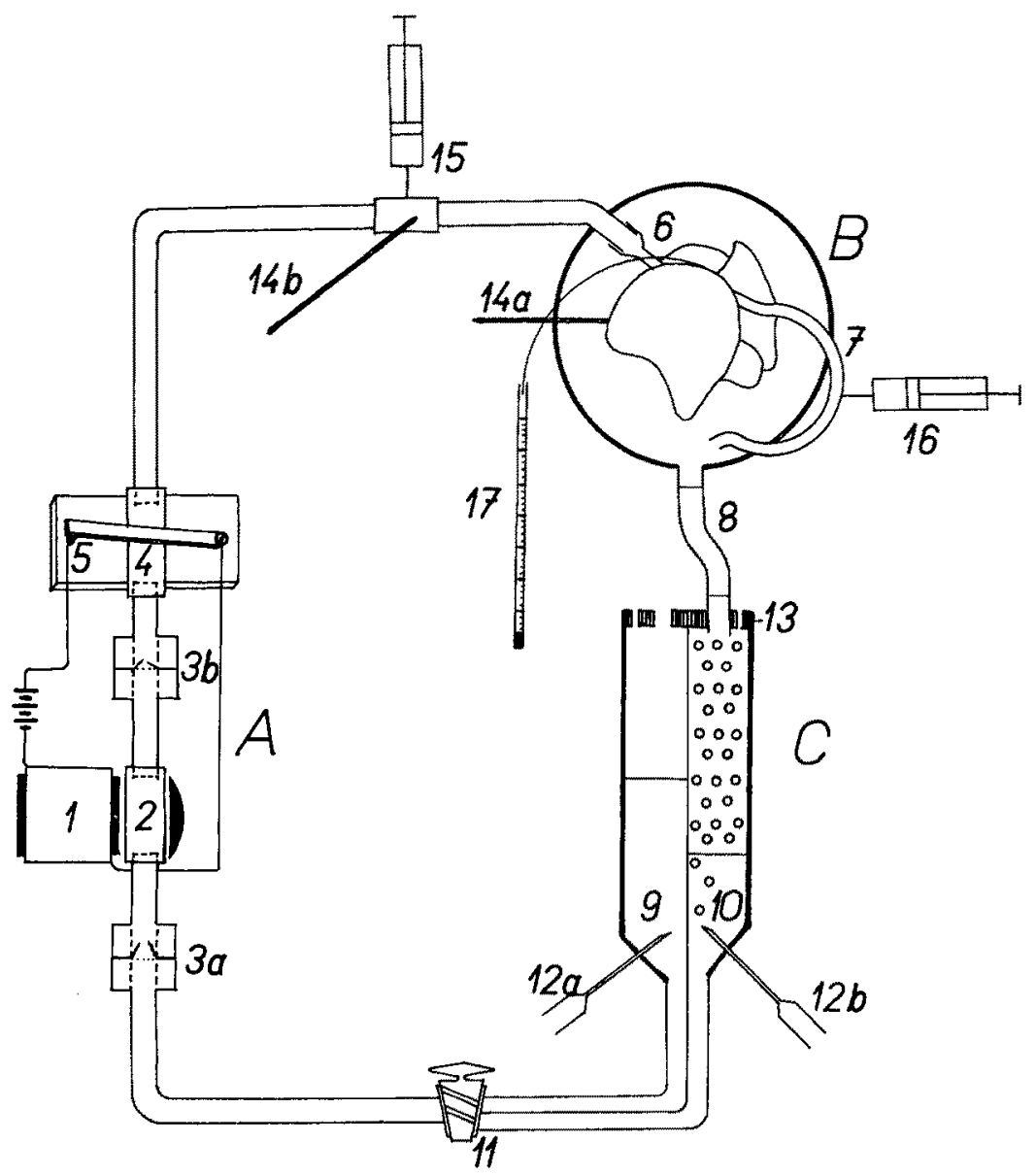

Fig. 1: Diagram of perfusion apparatus. Main parts: (A) pumping system, (B) liver chamber, (C) double blood reservoir and oxygenator. Details: (1) electromagnet, (2) rubber tube, $(3 a, 3 b)$ one-way valves, (4) relay tube, (5) relay contacts, (6) portal cannula, (7) cannula in vena cava inferior, (8) flow meter, $(9,10)$ blood reservoirs and oxygenators, (11) double stop-cod, $(12 \mathrm{a}, 12 \mathrm{~b})$, inflow of oxygen, (13) polyurethane sponge, $(14 \mathrm{a}, 14 \mathrm{~b})$ thermocouples,

$(15,16)$ sites where arterial and venous blood samples were taken, $(17)$ bile receptacle

liver and of the inflowing blood is measured by thermocouples (14a, 14b). The oxygen consumption is determined on the basis of arteriovenous differences in blood $\mathrm{O}_{2}$ content and of blood flow. Blood samples are taken by $0.25 \mathrm{~cm}$ syringes. The arterial sample is taken directly from the blood intake through a protective rubber strip (15), and the venous sample from the cannula in the vena cava inferior (16), which is 
carried out of the liver chamber in order to keep conditions in perfusion chamber constant during sampling of venous blood. The bile duct was also cannulated, and bile was collected into a calibrated test tube (17).

The valves $(3 \mathrm{a}, 3 \mathrm{~b})$, allowing blood flow only in one direction, are of particular importance. They are fitted with a nylon net pad and a very fine rubber membrane, cut through in the shape of a cross. These valves minimize turbulent streaming, and in this way only very small haemolysis occurs. The routes through which the perfusion fluid flows are partitioned by three net pads (two in the valves and one on the bottom of the blood reservoir), which do not allow possible blood clots to enter the liver. The whole apparatus is placed in a thermostat, and a temperature of $39^{\circ} \mathrm{C}$ is maintained.

Operation technique: Animals were weighed and anaesthetized by an intraperitoneal injection of Thiopental Spofa $(40 \mathrm{mg} / \mathrm{kg}$ ). Their abdominal cavity was opened, and the vena cava inferior was tied between the right kidney and the liver. The bile duct was cannulated, and a ligature under the vena portae was prepared. In order to prevent blood clotting, $0.1 \mathrm{ccm}$ Heparin ( $=100$ U.S.P. units, that is, about $0.1 \mathrm{mg}$ Heparin Elli Lilly $\mathrm{Co}$ ) was injected into the portal vein before cannulation. Then the cannulation of the portal vein was performed, and the liver was washed through by $5 \mathrm{ml}$ of tepid saline (Tyrode physiological solution). After opening the thoracic cavity and cutting the vena cava inferior about $0.5 \mathrm{~cm}$ under the heart, the liver was excised, weighed and connected with the apparatus. The vena cava inferior was then cannulated. The duration of anoxia (the interval between the incision of the cannula into the vena portae and the renewal of blood circulation in the liver in the apparatus) did not exceed 6 minutes. The cannulas were made from polyethylene tubes. Blood samples for oxygen content and glucose content determinations were taken after the adjustment of the rate of flow to $1 \mathrm{ml}$ of blood per $\mathrm{g}$ of liver per minute, and of equilibrating temperature to $39^{\circ} \mathrm{C}$. Simultaneously with the taking of samples, rate of flow, temperature of liver and blood, and bile production were registered.

Analytical methods: The oxygen content was determined volumetrically using the method described by Roughton \& Scholander (1943) and corrected to $O^{\circ} \mathrm{C}$ temperature and to $760 \mathrm{~mm} \mathrm{Hg}$. The calculated arteriovenous difference in oxygen content was multiplied by the rate of blood flow, and the estimated oxygen consumption was expressed as $\mathrm{ml} \mathrm{O}_{2}$ per $\mathrm{g}$ liver per hour. The glucose content in blood was measured by the method of DoležAL, Manoví, KÁcL \& KRÁsNÝ (1963) and by the method of SEIFTER et al. (1950), both in venous and arterial blood.

Other methodical details have been mentioned in previous publications (ZEIsBerger 1965, Zeisberger, Doležal \& Janskx́ 1967). 


\section{RESULTS AND DISCUSSION}

\section{Rate of oxidative metabolism in isolated perfused rat liver}

The conditions during the perfusion were maintained similar to those in vivo. The liver was perfused by a small amount $(20$ to $25 \mathrm{ml})$ of undiluted defibrinated rat blood (average hematocrit $43 \%$ ) taken from animals kept and treated in the same way as those used as liver donors. The liver blood flow was maintained at the rate of

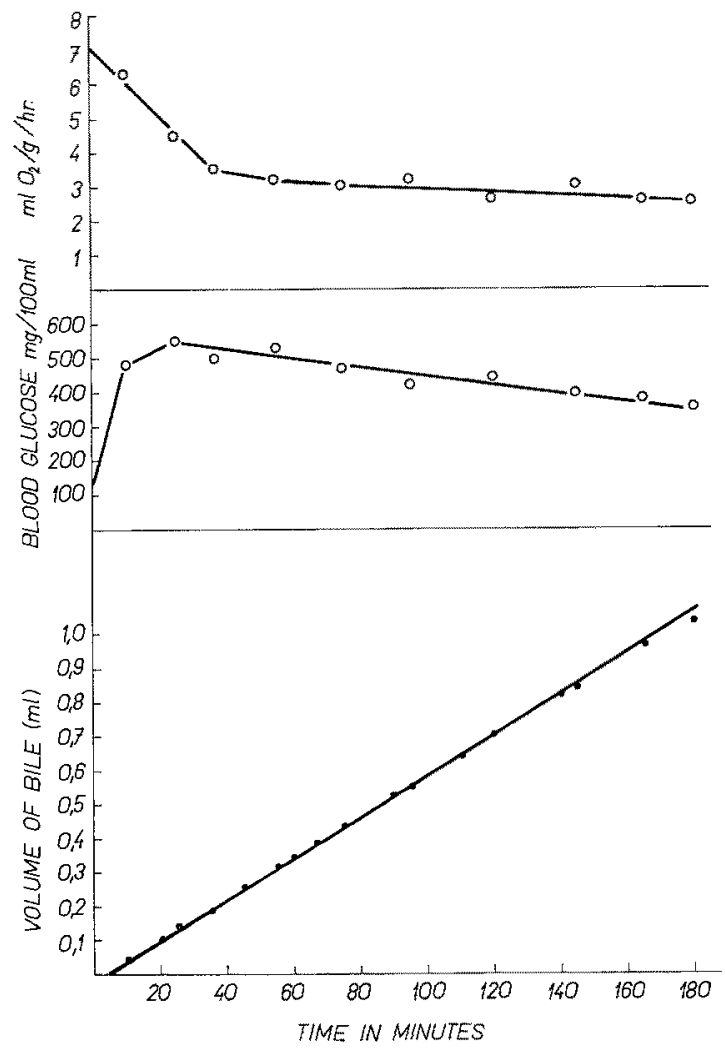

Fig. 2: Typical time course of perfusion experiment. Upper part: Changes in oxygen consumption of isolated perfused rat liver. Middle part: Changes in blood glucose content. Lower part: Bile production

$1 \mathrm{ml}$ per $\mathrm{g}$ of liver per minute, which corresponds roughly to in vivo conditions. The blood was oxygenated to a greater extent ( 16 to 18 volume $\% \mathrm{O}_{2}$ ) than in vivo to secure sufficient oxygen supply for the liver cells even when excluding arterial circulation. The experiments were performed at a temperature of $39^{\circ} \mathrm{C}$.

The oxygen consumption of isolated rat liver perfused by undiluted recirculating rat blood was not stable during the perfusion experiment, although the experimental 
conditions were maintained constant. Immediately after the start of perfusion oxygen consumption of the liver was relatively high ( 6 to $8 \mathrm{ml} \mathrm{O}$ per $g$ of liver per hour). During the first hour of perfusion the metabolism of the liver decreased to about a half of the original value. During the second and third hour of perfusion, the metabolism was relatively stable (Fig. 2). A similar course of oxygen consumption of perfused liver has been observed also by other authors (LundsGAard, Nielsen \&

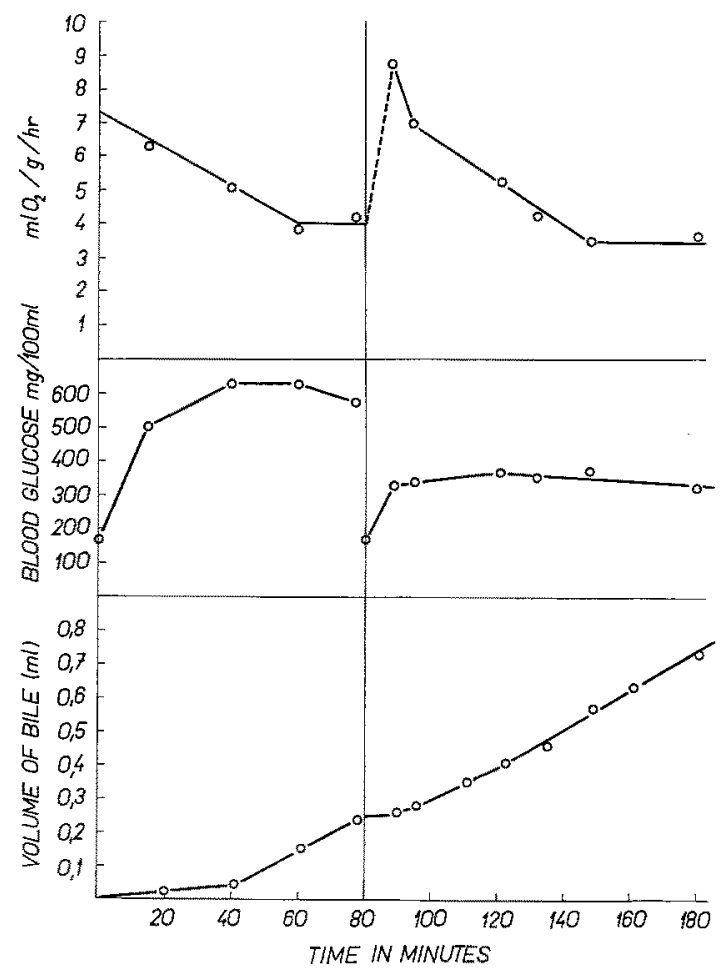

Fig. 3: Influence of perfusing blood exchange on rat liver oxidative metabolism

Orskov 1936, Lundsgand 1942, 1950, Bornstein \& Roese 1930, Brauer 1961, Ostashever, Gray \& Graff 1960. Schimassex 1962). Most authors assume that the oxygen consumption is increased immediately after the isolation of the organ because of overcoming of the surgical trauma, a certain period of anoxia and the interruption of blood circulation. Therefore, some authors do not measure the oxygen consumption immediately after the start of the perfusion (MISHKEL \& MORRIS 1963, JANSKÝ, ZEISBerger \& DOLEŽAl 1964, ForsANDER et al. 1965).

The average blood glucose level rose at the start of a perfusion from the rate $120 \mathrm{mg} \%$ to $360 \mathrm{mg} \%$. The rise of blood glucose level, apparently, caused by the effect of anoxia on the liver phosphorylase, was followed by a period of stable, slightly declining glucose level in the blood.

The bile production served as a criterion of the viability of isolated liver. The 
bile secretion was mostly stable during the experiment. At the standard perfusion conditions the average bile formation was $44 \mu \mathrm{l}$ of bile per $\mathrm{g}$ of liver per hour.

It is, however, also possible to consider the high oxidative metabolism of liver, measured immediately after the isolation of the organ, as the true metabolism of the liver and to explain the decline in liver metabolism by changes in the composition of the perfusion medium during recirculation, which could be caused by depletion of some substances in the blood or by possible accumulation of some metabolic products, which could inhibit metabolism.

If the decline of metabolism observed in our experiments is due to these causes, it would be possible to raise the oxygen consumption up to the original level by using fresh blood. The following experiment was therefore carried out (Fig. 3). A double amount of blood was used. One half of the blood was placed into the working space, and the other half was placed into the reserve space of the double blood reservoir. Then the liver was isolated from a cold acclimated rat and perfused for 80 minutes under standard perfusion conditions $\left(39^{\circ} \mathrm{C}\right.$, flow rate $1 \mathrm{ml} / \mathrm{g} / \mathrm{min}$, oxygenation 18 volume $\% \mathrm{O}_{2}$ ). We noticed typical changes: the decline of $\mathrm{O}_{2}$ consumption from the originally high level of $7.3 \mathrm{ml} \mathrm{O} / \mathrm{g} /$ hour to the level of about $4 \mathrm{ml} \mathrm{O} / \mathrm{g} /$ hour during 60 minutes and the rise of blood glucose level, caused apparently by the effect of anoxia on the liver phosphorylase.

After 80 minutes the old blood was replaced by new blood from the reserve space of the reservoir. Immediately after this exchange, a rise in $\mathrm{O}_{2}$ consumption to the level of $8.75 \mathrm{ml} \mathrm{O} / \mathrm{g} /$ hour was observed, followed by a progressive decrease, as in the first part of the experiment. After 67 minutes the oxygen consumption leveled down to $3.5 \mathrm{ml} \mathrm{O} / \mathrm{g} /$ hour. The rise of glucose level in the perfusate was considerably smaller than in the first part of the experiment, evidently because the period of anoxia was considerably shorter.

These results confirm our supposition that the decline of liver oxidative metabolism is caused by changes in the blood composition which occur during recirculation of the blood. Our results corresponded remarkably well with the results of LunDsGAARD (1950), who carried out similar experiments on isolated cat and rabbit livers. LUNDSGAARD did not achieve the complete renewal of the original level of liver metabolism since his method did not allow a complete blood exchange in the apparatus. However, the increase of oxygen consumption which he observed after the blood exchange was substantial, and its character and course were practically the same as the increase noted in our experiments. LUNDSGAaro also concluded that factors determining the $\mathrm{O}_{2}$ consumption of isolated liver are contained in the blood.

This view is supported by experiments of Murphy \& Muntz (1957). These authors perfused rat liver with a great quantity of blood (taken from about 100 rats), so that the blood passed through the liver only once. They obtained high $\mathrm{O}_{2}$ consumption (at the blood flow $1 \mathrm{ml} / \mathrm{g} /$ minute the $\mathrm{O}_{2}$ consumption was $8 \mathrm{ml} \mathrm{O} / \mathrm{g} / \mathrm{hour}$ ), and the value did not decrease during the whole experiment as long as the blood flow was kept constant.

On the basis of these results we come to the conclusion that the high $\mathrm{O}_{2}$ consumption of perfused liver, obtained at the start of the perfusion, corresponds to the resting $\mathrm{O}_{2}$ consumption of liver under in vivo conditions. 
This means that the normal value of rat liver oxidative metabolism is probably much higher (about 6 to $8 \mathrm{ml} \mathrm{O} / \mathrm{g} /$ hour) than was up supposed until now on the basis of experiments with liver slices and on the basis of perfusion experiments, in which a physiological solution or diluted blood was used as perfusion medium, or where the oxygen consumption was registered only a certain time after the commencement of the experiment. BRAUER (1963) recently came to similar conclusions.

\section{The resting liver metabolism of cold-and Warm-acclimated rats}

The rate of resting liver metabolism was estimated in livers isolated from cold- or warm-acclimated rats, perfused by blood of animals adapted in the same way, and the time course of changes in $\mathrm{O}_{2}$ consumption was studied (Fig. 4). Each curve is

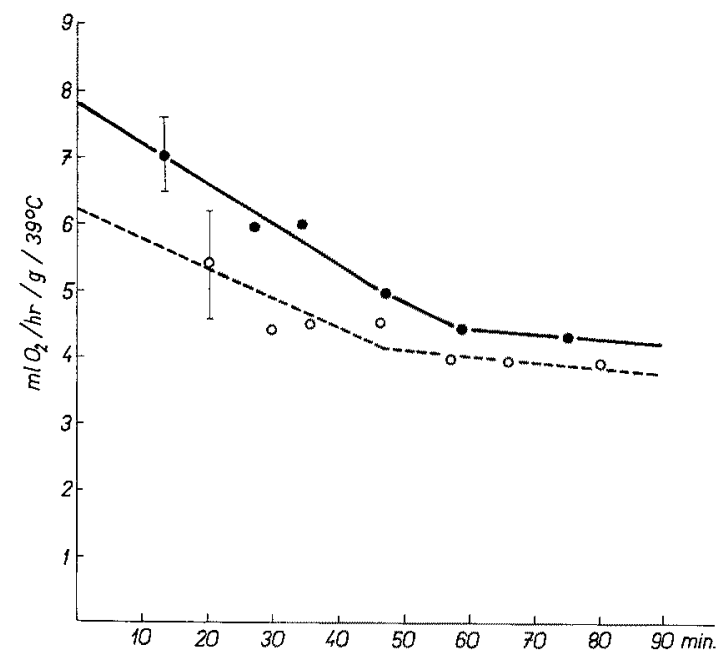

Fig. 4: Effect of acclimation on the time course of oxygen consumption of isolated rat liver perfused at standard perfusion conditions. ( 0 ) oxygen consumption of livers from rats acclimated to $30^{\circ} \mathrm{C}$; $(\bullet)$ oxygen consumption of livers from rats acclimated to $6^{\circ} \mathrm{C}$. Each curve is based on an average of 9 experiments. The statistically significant difference $(\mathrm{P}<0,05)$ between values obtained on livers from cold- and warm-acclimated rats was found only at the start of the experiment

based on the average of 9 experiments. A statistically significant difference between values obtained in livers from cold-and warm-acclimated rats was found only at the start of the experiment. Because we consider these values as being closest to the values of liver oxidative metabolism in vivo (see preceding chapter), it may be expected that the metabolic contribution of liver to the total metabolism will be different in coldand warm-acclimated rats. The difference in total liver $\mathrm{O}_{2}$ consumption between warm- and cold-acclimated rats is even greater because the relative participation of 
the liver weight in the total body weight is greater in cold-acclimated animals (Table 1).

By multiplying the average values of $\mathrm{O}_{2}$ consumption measured immediately after the isolation of the liver (i. e. $6.2 \mathrm{ml} \mathrm{O} / \mathrm{g} /$ hour for the liver of rats acclimated to $30^{\circ} \mathrm{C}$ and $7.8 \mathrm{ml} \mathrm{O} / \mathrm{g} /$ hour for the livers of rats acclimated to $6^{\circ} \mathrm{C}$ ) by the average weight of liver, we calculated that the liver of warm-acclimated rats has an $\mathrm{O}_{2}$ consumption of $62.9 \mathrm{ml} \mathrm{O} /$ hour and cold-acclimated rats of $77 \mathrm{ml} \mathrm{O}_{2} /$ hour, although

Table 1

Oxygen consumption of warm-and cold-acclimated animals

\begin{tabular}{|c|c|c|c|c|}
\hline $\begin{array}{l}\text { Acclimation } \\
\text { temperature }\end{array}$ & $\begin{array}{l}\text { Number } \\
\text { of animals }\end{array}$ & $\begin{array}{c}\text { Average weight } \\
\text { of rats }\end{array}$ & $\begin{array}{c}\text { Average weight } \\
\text { of livers }\end{array}$ & $\begin{array}{c}\text { Percentage } \\
\text { of liver } \\
\text { in body weight }\end{array}$ \\
\hline \multirow{3}{*}{$\begin{array}{r}30^{\circ} \mathrm{C} \\
6^{0} \mathrm{C}\end{array}$} & 9 & $320 \mathrm{~g}$ & $10.10 \mathrm{~g}$ & $3.15 \%$ \\
\hline & 9 & $241 \mathrm{~g}$ & $9.88 \mathrm{~g}$ & $3.70 \%$ \\
\hline & $\begin{array}{c}\text { Average liver } \\
\text { tissue } \\
\mathrm{O}_{2} \text { consumption }\end{array}$ & $\begin{array}{l}\text { Calculated } \\
\text { resting } \mathrm{O}_{2} \text { con- } \\
\text { sumption of rat }\end{array}$ & $\begin{array}{c}\text { Calculated } \mathrm{O}_{2} \\
\text { consumption } \\
\text { of liver }\end{array}$ & $\begin{array}{c}\text { Participation of } \\
\text { liver in basal } \\
\text { metabolism }\end{array}$ \\
\hline $30^{\circ} \mathrm{C}$ & $6.2 \mathrm{ml} \mathrm{O} / \mathrm{g} /$ hour & $320 \mathrm{ml} \mathrm{O} /$ hours & $62.9 \mathrm{ml} \mathrm{O}_{2} /$ hours & $19.60 \%$ \\
\hline $6^{\circ} \mathrm{C}$ & $7.8 \mathrm{ml} \mathrm{O} / \mathrm{g} /$ hour & $290 \mathrm{ml} \mathrm{O} /$ hours & $77.0 \mathrm{ml} \mathrm{O} /$ hours & $26.50 \%$ \\
\hline
\end{tabular}

the cold acclimated rats are almost $80 \mathrm{~g}$ lighter. The calculation of the participation of the liver metabolism in the total basal metabolism was based on the assumption that the basal metabolism of cold-acclimated rats is $20 \%$ higher in the zone of thermoneutrality than the metabolism of animals acclimated to warm (DEPOCAS, HART \& Heroux 1957; HaRT 1957).

On the basis of these results we can say that the liver metabolism amounts to $19.6 \%$ of the basal metabolism of rats acclimated to $30^{\circ} \mathrm{C}$ and to $26.5 \%$ of the basal metabolism of rats acclimated to $6^{\circ} \mathrm{C}$. The livers of rats acclimated to $6^{\circ} \mathrm{C}$ produce under basal conditions about $35 \%$ more heat than livers of rats acclimated to $30^{\circ} \mathrm{C}$. It is clear from these experiments that the participation of the liver heat production in the basal metabolism of rats is much higher than was supposed as a result of the measurement of $\mathrm{O}_{2}$ consumption in liver slices (10 to $12 \%$ : WEymouth, FIeld \& Kleiber 1942, Field, Belding \& Martin 1939, Krebs 1950, Martin \& Fuhrman $1955 ; 10$ to $18 \%$ : BeHnke 1958). The heat production of the liver under basal conditions does not have any thermoregulatory significance. To estimate whether the liver thermogenesis is used in thermoregulatory processes, we would have to know how the liver thermogenesis changes when animals are exposed to cold. Because it is impossible at present to measure the changes of liver metabolism directly, we tried to find the individual factors which may have an effect on liver thermogenesis. We hoped that the knowledge of these factors would allow us to estimate the possible extent of the changes of liver metabolism and to clarify its role in cold thermogenesis. 


\section{Factors influencing liver oxidative metabolism}

During the second and third hour of perfusion when the $\mathrm{O}_{2}$ consumption of isolated rat liver was stable, the effect of different factors on the oxidative liver metabolism was studied. It was found that the liver oxygen consumption and thus its thermogenesis are influenced by changes in the concentration of some substances in the blood. We found (Janskŕ, Zeisberger \& Doležal 1964, Zeisberger, Doležal \& JANSKÝ 1967) that the oxygen consumption $(\mathrm{Q}=\mathrm{ml} \mathrm{O} / \mathrm{g}$ of liver/hour) of isolated perfused livers of cold-acclimated rats depends on the supply of oxygen, $Q=0.79$ (oxygenation in vol $\left.\% \mathrm{O}_{2}\right)^{\mathbf{0 . 5 6}}$, and on the rate of blood flow through the organ, $\mathrm{Q}=3.73$ (flow in $\mathrm{ml} / \mathrm{g}$ of liver $/ \mathrm{min})^{0.47}$.

Also some hormones and metabolic substrates exert an effect on the $\mathrm{O}_{2}$ consumption of isolated liver. Glycin and $\beta$-hydroxybutyrate raise the oxygen consumption of isolated liver by $60 \%$ or $40 \%$ respectively. Insulin also increase the $\mathrm{O}_{2}$ consumption by about $60 \%$. On the other hand, no effect of noradrenaline on $\mathrm{O}_{2}$ consumption of the liver was observed. These experiments, even if they were not performed under entirely in vivo conditions, show that the participation of the liver in noradrenaline stimulated thermogenesis is probably negligible and indicate that the intensity of liver metabolism could be a function of oxygen and substrates supplies. This fact is rather surprising since under in vitro conditions the metabolism of liver cells seems to be regulated by ADP availability and not by substrates supply. Some other mechanisms acting at organ level must therefore be expected in regulation of total liver metabolism.

It is clear from these results that liver metabolism can be affected by changes in concentration of different substances in the blood and by changes in blood flow. These factors can almost double the resting $\mathrm{O}_{2}$ consumption of the liver.

However, the question remains whether the organism can use this thermogenesis for thermoregulation and whether liver thermogenesis increases substantially after exposure of the organism to cold. There is some evidence that liver thermogenesis is small, and there is a possibility that in man the relative metabolic contribution of the liver could even decline in cold, owing to relatively great muscular heat production. This supposition is indicated by lowered splanchnic blood flow during greater muscular exertion (BRADLEY 1949). Also the experiments on functionally eviscerated rats exposed to cold do not indicate any significance of the liver in cold thermogenesis (Depocas 1958, 1960b).

On the other hand, several facts show that the liver could participate in cold thermogenesis, mainly in regard to the effect of catecholamines (the role of which in the reaction and adaptation to cold is well known) on the liver blood flow (Hannon, EvonuK \& LARSON 1963), on substrates concentration in the blood (HANNON \& LARSEN 1962, Rimmer, SChönbaum \& Sellers 1962) and on the splanchnic oxygen consumption (Bearn, Billing \& Sherlock 1951). Therefore, it is possible to expect an indirect effect of noradrenaline and other hormones on the liver thermogenesis. We assume the existence of a thermogenetic mechanism consisting of the hormone influence on the liver metabolism by changes in substrate concentrations in the blood and by blood flow changes (ZEISBERger 1965, JANSKÝ 1966). 


\section{SUMMARY}

1. Liver thermogenesis was determined by measuring the oxidative metabolism of isolated perfused rat liver.

2. Metabolism of isolated liver decreases during the perfusion experiment even when perfusion conditions are maintained constant. This decrease of metabolism is caused by changed blood composition occuring in the course of its recirculation. It can be concluded that only the highest level of oxygen consumption of isolated liver measured at the beginning of the perfusion experiment or after blood exchange during the experiment corresponds to the level of resting liver metabolism in vivo. On the basis of this finding it is necessary to assume that resting liver metabolism is much higher (about 6 to $8 \mathrm{ml} \mathrm{O} / \mathrm{g}$ of liver/hour) than was previously thought as a result of the measurement of $\mathrm{O}_{2}$ consumption of liver slices.

3. Livers and blood of rats (Sprague-Dawley strain) acclimated to warm $\left(30^{\circ}\right)$ or cold $\left(6^{\circ} \mathrm{C}\right)$ were used. The average resting $\mathrm{O}_{2}$ consumption of liver isolated from cold-acclimated rats $(7.8 \mathrm{ml} \mathrm{O} / \mathrm{g} /$ hour $)$ differs significantly from the liver $\mathrm{O}_{2}$ consumption of warm-acclimated rats $(6.2 \mathrm{ml} \mathrm{O} / \mathrm{g} /$ hour $)$. Therefore, liver metabolism amounts to $19.3 \%$ of the basal metabolism in warm-acclimated and to $26.5 \%$ in cold-acclimated rats. Under basal conditions livers of rats acclimated to $6^{\circ} \mathrm{C}$ produce about $35 \%$ more heat than livers of rats acclimated to $30^{\circ} \mathrm{C}$.

4. The utilization of liver thermogenesis for thermoregulatory purposes on exposure of the organism to cold can be estimated only roughly on the basis of changes of factors affecting the liver oxidative metabolism. Oxygen consumption of isolated perfused liver depends on perfusion factors connected with supplying the liver with oxygen, the rate of liver blood flow, temperature of environment and on metabolic factors connected with the content of metabolic substrates and hormones in the perfusion medium. These factors can increase the resting oxygen consumption of the liver.

5. We assume the existence of a thermogenetic mechanism, consisting of the hormone influence on the liver metabolism via changes in substrates concentration in the blood and by blood flow changes. However, there is some evidence that the quantitative significance of this thermogenetic mechanism is restricted.

We are indepted to Mrs. J. Kuimentoví for technical assistance and for the preparation of illustrations.

\section{LITERATURE CITED}

Bearn, A. F., Billing, B. \& Sherlock, S., 1951. The effect of adrenaline and noradrenaline on hepatic blood flow and splanchnic carbohydrate metabolism in man. J. Physiol., Lond. 115, 430-441.

Behnke, Jr., A. R., 1958. The liver in relation to the body as a whole. In: Liver function. Ed. by R. W. Brauer. Am. Inst. Biol. Sci., Washington, D. C., 43-58.

Bornstern, A. \& Roese, H. F., 1930. Uber die Beeinflussung des Sauerstoffverbrauches überlebender Organe durch Glykokoll (Untersuchungen zur Frage der spezifischdynamischen Wirkung des Glykokolls). Pflügers Arch. ges. Physiol. 223, 498-508. 
BradeEY, S. E., 1949. Variations in hepatic blood flow in man during health and disease. New Engl. J. Med. 240, 456-461.

Brauer, R. W., 1961. Liver circulation, liver function and liver integrity. Trans. Stud. Coll. Physns Philad. 29, 49-65.

- 1963. Liver circulation and function. Physiol. Rev. 43, 115-213.

Depocas, F., 1958. Chemical thermogenesis in the functionally eviscerated cold-acclimated rat. Can. J. Biochem. Pbysiol. 36, 691-699.

- 1960a. The calorigenic response of cold-acclimated white rats to infused noradrenaline. Can. J. Biochem. Physiol. 38, 107-114.

- 1960b. Calorigenesis from various organ system in the whole animal. Fedn Proc. Fedn Am. Socs exp. Biol. 19, 19-24.

- Hart, J. S. \& Heroux, O., 1957. Energy metabolism of the white rat after acclimation to warm and cold environments. J. appl. Physiol. 10, 393-397.

Doležal, V., Manová, I., KácL, K. \& KRÁsnÝ, J., 1963. Die kinetische Mikromethode zur Bestimmung der Glukose im Blut. Z. ges. inn. Med. 18, 1093-1095.

- ZeIsberger, E. \& JanskÝ, L., 1963. Perfusní př́stroj měření metabolismu isolovaných krysích jater. Čslká fysiol. 12, 352-353.

Field, J, Belding, H. S. \& Martin, A. W., 1939. An analysis of the relation between basal metabolism and summated tissue respiration in the rat. 1 . The post-pubertal albino rat. J. cell. comp. Pbysiol. 14, 143-158.

Forsander, O. A., RÄrḦ̈, N., Salaspuro, M. \& MäenpäA, P., 1965. Influence of ethanol on the liver metabolism of fed and starved rats. Biochem. J. 94, 259-265.

Graf, W., 1959. Patterns of human liver temperature. Acta physiol. scand. 46 (Suppl. 160), $1-135$.

Hannon, J. P., Evonuk, E. \& Larson, A. M., 1963. Some physiological and biochemical effect of norepinephrine in cold-acclimatized rat. Fedn Proc. Fedn Am. Socs exp. Biol. 22, $783-787$.

- \& Larson, A. M., 1962. Fatty acid metabolism during norepinephrine - induced thermogenesis in the cold-acclimatized rat. Am. J. Physiol. 203, 1055-1061.

Hart, J. S., 1957. Climatic and temperature-induced changes in the energetics of homeotherms. Revue can. Biol. 16, 133-174.

JANsKÝ, L., 1963. Body organ cytochrome oxidase activity in cold- and warm-acclimated rats. Can. J. Biochem. Physiol. 41, 1847-1854.

- 1965. Adaptability of heat production mechanisms in homeotherms. Acta Univ. Carol. (Biol.) 1965 (1), 1-91.

- 1966. Body organ thermogenesis of the rat during exposure to cold and at maximal metabolic rate. Fedn Proc. Fedn Am. Socs exp. Biol. 25, 1297-1302.

- \& HART, J. S., 1963. Participation of skeletal muscle and kidney during nonshivering thermogenesis in cold-acclimated rats. Can. J. Biochem. Pbysiol. 41, 953-964.

-- Zetsberger, E. \& DOLEŽAL, V., 1964. Effects of oxygen supply and noradrenaline infusion on liver metabolism of rats acclimatized to cold. Nature, Lond. 202, 397-398.

KREBS, H. A., 1950. Body size and tissue respiration. Biochim. biophys. Acta 4, 249-269.

Lundsganar, E., 1942. The specific dynamic action of amino acids and ammonia salts. Acta physiol. scand. 4, 330-348.

- 1950. Observations on a factor determining the metabolic rate of the liver. Biochim. biophys. Acta 4, 322-329.

- Nielsen, N. A. \& Orskov, S. L., 1936. The carbohydrate metabolism of the isolated cat liver. Skand. Arch. Physiol. 73, 296-313.

Martin, A. W. \& Funrman, F. A., 1955. The relationship between summated tissue respiration and metabolic rate in the mouse and dog. Physiol. Zool. 28, 18-34.

Mrshkel, M. A. \& Morris, B., 1963. The gaseous metabolism of the isolated perfused normal and choline deficient rats liver. Quart. Jl exp. Physiol. 48, 202-208.

Murphy, J. R. \& Muntz, J. A., 1957. The metabolism of glucose in the perfused rat liver. J. Biol. Chem. 224, 987-997. 
Ostashever, A. S., Gray, I. \& GrafF, S., 1960. Metabolic characteristics of the isolated perfused rat liver. Am. J. Physiol. 199, 395-399.

Rimmer, A. D., Sснönbaum, E. \& Sellers, E. A. 1962. Effect of norepinephrine on blood glucose and free fatty acids in cold-adapted rats. Am. J. Physiol. 203, 95-97.

Roughton, F. J. W. \& Scholander, P. F. 1943. Micro-gasometric estimation of the blood gases. 1. Oxygen. J. Biol. Chem. 148, 541-550.

Schimassek, $H ., 1962$. Perfusion of isolated rat liver with semisynthetic medium and control of liver function. Life Sci., Oxf. 11, 629-634.

Seifter, S., Dayton, S., Novic, B. \& Muntwyler, E., 1950. The estimation of glycogen with anthrone reagent. Arch. Biochem. 25, 191-200.

Weymouth, F. W., FIELD, H. J. \& KuExBER, M., 1942. Relationship between body size and metabolism. Proc. Soc. exp. Biol. Med. 49, 367-370.

ZEISBERGER, E., 1965. Oxydativní metabolismus isolovaných perfundovaných jater a význam jater pro thermogenesi. PhD Thesis, Charles Univ. Prague 1965.

- Doležal, Y. \& JANSKÝ, L., 1967. Influence of some perfusion factors on isolated rat liver oxidative metabolism. Pbysiologia Bobemoslov. (in press).

\section{Discussion following the paper by ZEISBERGER}

PRECHT: Welche Unterschiede erhalten Sie, wenn Sie die Leber eines warmadaptierten Tieres nehmen, und sie mit dem Blut eines kaltadaptierten durchströmen oder umgekehrt?

ZEISBERGER: Experiments of that type are just now in progress.

LOCKER: Es ist interessant, daß auch bei der intakten perfundierten Leber der $\mathrm{O}_{2}$-Verbrauch absinkt und man nur dadurch über dex tatsächlich in vivo stattfindenden $\mathrm{O}_{2}$-Verbrauch eine Aussage machen kann, daß man aus diesem Abfall auf $\mathrm{t}_{0}$ extrapoliert. Das gleiche trifft auch zu für den $\mathrm{O}_{2}$-Verbrauch von Gewebsschnitten in vitro, vor allem der Leber (Z. ges. exp. Med. $127,1,1956)$. Dieser Befund zeigt, daß auch perfundierte Organe nicht unter idealen methodischen Bedingungen vorliegen, aber auch, daß die Warburg-Technik zur Erfassung von invivo-Verhältnissen ausreicht. 